\title{
Selected aspects of patients' functioning before and after desensitization with specific allergen immunotherapy
}

\author{
Wybrane aspekty funkcjonowania pacjentów przed i po odczulaniu swoistą immunoterapią \\ alergenową
}

\section{Ewa Kawalec-Kajstura', Magdalena Chomicka², Joanna Sułkowska², Grażyna Puto ${ }^{4}$, Illona Kuźmicz'}

ZZakład Pieleggniarstwa Internistycznego i Środowiskowego, Instytut Pielęgniarstwa i Położnictwa,

Wydział Nauk o Zdrowiu, Uniwersytet Jagielloński Collegium Medicum, Kraków, Polska/

Department of Internal Medicine and Community Nursing, Institute of Nursing and Midwifery,

Faculty of Health Sciences, Jagiellonian University Medical College (JU MC), Krakow IInstytut Pielęgniarstwa i Położnictwa, Wydział Nauk o Zdrowiu, Uniwersytet Jagielloński Collegium Medicum, Kraków, Polska - absolwent/

Faculty of Health Sciences, Jagiellonian University Medical College (JU MC), Krakow - graduate ${ }^{3}$ doktorantka w Zakładzie Pielęgniarstwa Internistycznego i Środowiskowego, Instytut Pielęgniarstwa i Położnictwa, Wydział Nauk o Zdrowiu, Uniwersytet Jagielloński Collegium Medicum, Kraków, Polska/

Department of Internal Medicine and Community Nursing, Institute of Nursing and Midwifery, Faculty of Health Sciences, Jagiellonian University Medical College (JU MC), Krakow - PhD student ${ }^{4}$ Zakład Pielęgniarstwa Klinicznego, Instytut Pielęgniarstwa i Położnictwa,

Wydział Nauk o Zdrowiu, Uniwersytet Jagielloński Collegium Medicum, Kraków, Polska/ Department of Clinical Nursing, Institute of Nursing and Midwifery, Faculty of Health Sciences, Jagiellonian University Medical College (JU MC), Krakow

Ewa Kawalec-Kajstura: 0000-0002-8754-147X Joanna Sułkowska: 0000-0002-4601-1544 Grażyna Puto: 0000-0002-0829-327X Ilona Kuźmicz: 0000-0001-5947-7442

CORRESPONDING AUTHOR/AUTOR DO KORESPONDENCJI:

Ewa Kawalec-Kajstura

Instytut Pielęgniarstwa i Położnictwa UJ CM

ul. Kopernika 25, 31-501 Kraków e-mail: e.kawalec@uj.edu.pl

Wprowadzenie. Choroby alergicznie są jednym z ważniejszych problemów zdrowotnych, przekładających się na występowanie różnego typu uciążliwości. Wśród metod mających na celu leczenie tych chorób, coraz bardziej powszechne staje się stosowanie swoistej alergenowej immunoterapii (Specific Allergen Immunotherapy - SAI). Jednakże, podejście to wymaga wysokiej adherencji do leczenia, co może wpływać na jakość życia pacjentów.

Cel pracy. Ocena jakości życia i codziennego funkcjonowania w grupie pacjentów, którzy stosowali swoistą immunoterapię alergenową.

Materiał i metody. Grupę badaną stanowiło 80 osób dorosłych, które zdecydowały się na zastosowanie SAI oraz leczyły się w dwóch małopolskich placówkach. Badanie obejmowało ocenę jakości życia oraz wybranych aspektów funkcjonowania (oraz ich retrospektywną ocenę). Zastosowane metody to: autorska ankieta oraz skrócona wersja ankiety the World Organization Quality of Life-BREF.

Wyniki. Zastosowanie SAI pozwoliło na zredukowanie częstości ( $M e=4,00$ do 2,00; $p<0,001)$ i nasilenia objawów $(M e=4,00$ do 2,00; $p<0,001)$ związanych z alergią. Zmniejszyła się także uciążliwość objawów alergii ( $M e=4,00$ do 2,00; $p<0,001)$. Ponadto, zaobserwowano poprawę w zakresie ogólnego dobrostanu $(\mathrm{Me}=4,00$ do 5,00; $p<0,001)$ oraz satysfakcji życiowej $(\mathrm{Me}=4,00$ do 5,00; $p<0,001)$.

Wnioski. Swoista terapia alergenowa wydaje się być wartym rozważenia podejściem wpływającym na poprawę satysfakcji życiowej pacjentów oraz zmniejszenie uciążliwości związanych z samą alergią. 
Introduction. Allergic diseases belong to the most important health problems responsible for the incidence of various types of discomfort. The application of specific allergen therapy (SAI) is becoming a more and more frequent method aimed at treating allergic diseases. However, this approach requires a strict adherence to medical treatment, which may affect patients' quality of life. Aim. Assessment of quality of life and everyday functioning in the group of patients who underwent a specific allergen therapy. Material and methods. The study group consisted of 80 adult patients who decided to undergo SAI treatment and were treated in two health care facilities in Małopolska region. The study included an assessment of life quality and selected aspects of functioning (as well as their retrospective assessment). As far as the applied methods are concerned, the study was based on the authors' own questionnaire and an abbreviated version of the World Organization Quality of Life-BREF questionnaire.

Results. SAl treatment made it possible to reduce both the incidence ( $\mathrm{Me}=4.00$ to 2.00; $\mathrm{p}<0.001$ ) and intensity ( $\mathrm{Me}=4.00$ to 2.00; $\mathrm{p}<0.001$ ) of allergic symptoms. Also the discomfort caused by the allergy was decreased ( $\mathrm{Me}=4.00$ to $2.00 ; \mathrm{p}<0.001)$. Moreover, some improvement in general well-being ( $\mathrm{Me}=4.00$ to $5.00 ; p<0.001)$ and life satisfaction $(\mathrm{Me}=4.00$ to $5.00 ; p<0.001)$ was observed.

Conclusions. Specific allergen immunotherapy seems to be worth considering as it improves patients' life satisfaction and reduces discomfort caused by the allergy itself.

\section{INTRODUCTION}

Allergic diseases are becoming a more and more common health problem in Poland [1], what corresponds to a European trend [2]. The European Academy of Allergy and Clinical Immunology [2] predicts that in 2015 allergic diseases will affect every other person living in Europe. It should be pointed out that allergic diseases have a significant influence on everyday routines because they cause numerous ailments, e.g. allergic rhinitis, cough, eye lacrimation [3] and limitations which affect patients' quality of life [4-5]. Among available methods of treatment it is specific allergen immunotherapy that is gaining in popularity as it seems particularly beneficial because of patient's comfort and relieving most symptoms connected with the allergy [3].

\section{AIM}

The aim of the study was the assessment of quality of life and everyday functioning in a group of patients who had been undergoing specific allergen immunotherapy (SAI) for at least 10 months.

\section{MATERIALS AND METHODS}

The study was conducted between 31 July and 31 August 2018 in two Małopolska region health facilities which treat allergies with the application of specific allergen immunotherapy. Before the study started, the authors obtained the consent of the authorities of both aforementioned facilities. Every patient was informed that his/ her participation in the study is voluntary, that they are guaranteed complete anonymity and that the results of the study will be used only for scientific purposes. Participants were informed about the aim of the study and the possibility to withdraw at any point. The study was conducted in accordance with the principles of the Declaration of Helsinki. Every patient gave his/her informed consent to participate in the study.
As many as 80 people were examined in the study, all of whom had been treated with specific allergen immunotherapy for at least 10 months. The respondents were aged between 18 and $63(\mathrm{M}=33.90 ; \mathrm{SD}=7.29)$. The research tools included the authors' own questionnaire and an abbreviated version of World Health Organization Quality of Life - BREF (WHOQOL-BREF), which are presented below.

The authors' own questionnaire consisted of two parts. The first one included questions about sociodemographic data, i.e. gender, age, place of residence, education, type of work, and financial status. It also included questions about the allergy itself, i.e. its diagnosis and type, coexisting symptoms, the incidence of asthma, type of pharmaceutical and immunotherapy measures taken, period (in months) for which specific allergen immunotherapy was applied and the advantages and disadvantages of this type of therapy. The other part, in turn, consisted of questions which referred to patients' condition before and after specific allergen immunotherapy (SAI). The questions dealt with patients' health condition, the incidence and intensity of allergy symptoms and the discomfort they cause and also with the consequences of such a condition, i.e. the need to modify everyday routines, the incidence of low mood and anger caused by the allergy as well as its impact on life satisfaction. These variables were assessed on a 0 to 6 scale. The scale description was adjusted to the content of particular questions. For example, while assessing "general health condition" 0 meant "very bad" and 6 - "very good".

The World Health Organization Quality of Life BREF (WHOQOL-BREF) - an instrument used for assessing the quality of life, which consists of 26 questions concerning the quality of life in its various aspects: health, physical, psychological, social and environmental one [6]. Each question is rated according to Likert scale with the scores ranging from 1 to 5 and its additional description is adjusted to particular problems. It is possible to obtain individual scores referring to the general health condition, general quality of life and also to each of its aspects. There are two ways of calculating the scores and this study 
applies the scale ranging from 1 to 100 , which makes it possible to compare the obtained results with the results of other studies which also address the issue of the quality of life [7].

A statistical analysis of the study findings was conducted with the application of Statistica 13.1 program. Shapiro-Wilk test was used to check the compliance of the variables with a normal distribution. Because of the lack of the aforementioned compliance Wilcoxon test for paired samples was used, which made it possible to examine variability within particular groups connected with the repeated examination (before and after specific allergen immunotherapy). In all analyses the level of significance was assumed as $\alpha=0.05$.

The respondents were asked to assess their current quality of life based on WHOQOL-BREF scale. Moreover, they were asked to carry out the assessment (both current and retrospective one) of selected aspects of their functioning with the application of the authors' own questionnaire.

\section{RESULTS}

The period during which the specific allergen immunotherapy was applied ranged from 10 to 80 months $(\mathrm{M}=26.81, \mathrm{SD}=14.89)$. It should be pointed out that $72.50 \%$ of the respondents considered this type of desensitization to be effective, whereas the other respondents found it difficult to make a clear-cut assessment of the effectiveness of this treatment.

The quality of life assessed by means of WHOQOL- BREF questionnaire was rated as "very good" by 31 patients (38.75\%), "good" by 45 respondents $(56.25 \%)$ and only 4 patients (5.00\%) believed it was "neither good nor bad". The average assessment of the quality of life and health showed the following results: quality of life $86.75 \%$, and health $-76.50 \%$. Detailed results are presented in Table 1.

Most respondents was satisfied with their health: 9 patients $(11.25 \%)$ declared that they were "very satisfied", 50 patients $(62.50 \%)$ said they were "satisfied", 19 people (23.75\%) said they were "neither satisfied nor dissatisfied" and 2 people $(2.50 \%)$ claimed they were "dissatisfied".

Tab. 1. Assessment of quality of life and health based on an abbreviated version of World Health Organization Quality of Life-BREF scale (WHOQOL-BREF)

\begin{tabular}{|l|c|c|c|c|c|c|c|}
\hline $\begin{array}{c}\text { WHOQ0L-BREF } \\
\text { [\%] }\end{array}$ & $\mathbf{M}$ & $\mathbf{M e}$ & $\mathbf{M i n}$ & $\mathbf{M a x}$ & $\mathbf{Q 1}$ & $\mathbf{Q 3}$ & $\mathbf{S D}$ \\
\hline Quality of life & 86.75 & 80.00 & 60.00 & 100.00 & 80.00 & 100.00 & 11.45 \\
\hline Health & 76.50 & 80.00 & 40.00 & 100.00 & 60.00 & 80.00 & 13.03 \\
\hline Physical aspect & 72.49 & 69.00 & 38.00 & 100.00 & 69.00 & 81.00 & 12.38 \\
\hline $\begin{array}{l}\text { Psychological } \\
\text { aspect }\end{array}$ & 77.25 & 75.00 & 44.00 & 100.00 & 69.00 & 88.00 & 11.15 \\
\hline Social aspect & 74.61 & 75.00 & 19.00 & 100.00 & 69.00 & 81.00 & 18.16 \\
\hline $\begin{array}{l}\text { Environmental } \\
\text { aspect }\end{array}$ & 72.58 & 75.00 & 44.00 & 100.00 & 63.00 & 81.00 & 11.99 \\
\hline
\end{tabular}

Legend: $\mathrm{n}$ - number of respondents; $\mathrm{M}$ - average; Me - median; Min - minimum; Max - maximum; SD - standard deviation; $Q 1$ - lower quartile; $Q 3$ - upper quartile;

WHOQOL-BREF - an abbreviated version of World Health Organization Quality of Life scale.

Source materials: Study based on the authors' own research.

Vol.18, $\mathrm{Nr} 4(69) / 2019$
As far as the assessment of functioning before and after SAI treatment is concerned, statistically significant changes were observed in, among others, general well-being (from $\mathrm{Me}=4.0$ to $5.0 ; \mathrm{p}<0.001$ ), the level of exacerbation of allergy symptoms (from Me 4.00 to 2.00; $<<0.001$ ), the incidence of allergy symptoms (from Me 4.00 to $2.00 ; \mathrm{p}<0.001)$ and the general level of life satisfaction (from $\mathrm{Me}=4.00$ to 5.00; $\mathrm{p}<0.001$ ). Detailed information about the results obtained by means of the authors' own questionnaire is presented in Table 2.

\section{DISCUSSION}

The aim of the study was the assessment of quality of life and the influence of applied treatment on daily functioning of patients undergoing specific allergen immunotherapy for at least 10 months. At least 80 adult patients were examined, all of whom were treated in one of the two hospitals in Małopolska region which provide such desensitization treatment. On average the participants of the study had been undergoing specific allergen immunotherapy for 26 months. All respondents completed the authors' own questionnaire and an abbreviated version of WHOQOL-BREF scale.

Tab. 2. Assessment of patients' functioning before and after introducing specific allergen immunotherapy (SAI)

\begin{tabular}{|c|c|c|c|c|c|c|c|c|}
\hline $\begin{array}{c}\text { Assessment scale } \\
{\left[0-6 \mathrm{pt} .^{*}\right]}\end{array}$ & SAI & M & SD & Me & Min & Max & $\mathbf{Z}$ & $\mathbf{p}$ \\
\hline \multirow{2}{*}{ General well-being } & before & 4.26 & 1.12 & 4.00 & 0.00 & 6.00 & \multirow{2}{*}{4.02} & \multirow{2}{*}{$<0.001$} \\
\hline & after & 4.85 & 0.86 & 5.00 & 2.00 & 6.00 & & \\
\hline \multirow{2}{*}{$\begin{array}{l}\text { Level of exacerbation of } \\
\text { allergy symptoms }\end{array}$} & before & 4.36 & 1.14 & 4.00 & 1.00 & 6.00 & \multirow{2}{*}{7.17} & \multirow{2}{*}{$<0.001$} \\
\hline & after & 2.38 & 1.30 & 2.00 & 0.00 & 6.00 & & \\
\hline \multirow{2}{*}{$\begin{array}{l}\text { Frequency of the } \\
\text { incidence of allergy } \\
\text { symptoms }\end{array}$} & before & 4.23 & 1.18 & 4.00 & 1.00 & 6.00 & \multirow{2}{*}{6.90} & \multirow{2}{*}{$<0.001$} \\
\hline & after & 2.28 & 1.25 & 2.00 & 0.00 & 6.00 & & \\
\hline \multirow{2}{*}{$\begin{array}{l}\text { Number of months } \\
\text { in a year with exacerbation } \\
\text { of allergy symptoms }\end{array}$} & before & 5.04 & 2.66 & 4.00 & 1.00 & 12.00 & \multirow{2}{*}{5.36} & \multirow{2}{*}{$<0.001$} \\
\hline & after & 3.55 & 2.29 & 3.00 & 1.00 & 12.00 & & \\
\hline \multirow{2}{*}{$\begin{array}{l}\text { Frequency of taking } \\
\text { anti-allergic medicines }\end{array}$} & before & 4.06 & 1.67 & 4.00 & 0.00 & 6.00 & \multirow{2}{*}{6.17} & \multirow{2}{*}{$<0.001$} \\
\hline & after & 2.29 & 1.82 & 2.00 & 0.00 & 6.00 & & \\
\hline \multirow{2}{*}{$\begin{array}{l}\text { The level of discomfort } \\
\text { caused by allergy } \\
\text { symptoms in everyday life }\end{array}$} & before & 4.01 & 1.32 & 4.00 & 1.00 & 6.00 & \multirow{2}{*}{6.87} & \multirow{2}{*}{$<0.001$} \\
\hline & after & 1.95 & 1.40 & 2.00 & 0.00 & 6.00 & & \\
\hline \multirow{2}{*}{$\begin{array}{l}\text { Willingness to do } \\
\text { sports activities during } \\
\text { exacerbation of allergy } \\
\text { symptoms }\end{array}$} & before & 2.28 & 1.68 & 2.00 & 0.00 & 6.00 & \multirow{2}{*}{5.05} & \multirow{2}{*}{$<0.001$} \\
\hline & after & 3.39 & 1.72 & 4.00 & 0.00 & 6.00 & & \\
\hline \multirow{2}{*}{$\begin{array}{l}\text { Necessity to change } \\
\text { everyday routines due to } \\
\text { allergy symptoms }\end{array}$} & before & 2.42 & 1.57 & 3.00 & 0.00 & 6.00 & \multirow{2}{*}{4.81} & \multirow{2}{*}{$<0.001$} \\
\hline & after & 1.63 & 1.50 & 1.00 & 0.00 & 6.00 & & \\
\hline \multirow{2}{*}{$\begin{array}{l}\text { Incidence of lowered } \\
\text { mood and anger due to } \\
\text { exacerbation of allergy } \\
\text { symptoms }\end{array}$} & before & 3.21 & 1.55 & 3.00 & 0.00 & 6.00 & \multirow{2}{*}{6.63} & \multirow{2}{*}{$<0.001$} \\
\hline & after & 1.88 & 1.36 & 2.00 & 0.00 & 6.00 & & \\
\hline \multirow{2}{*}{$\begin{array}{l}\text { Level of general life } \\
\text { satisfaction }\end{array}$} & before & 4.28 & 0.90 & 4.00 & 1.00 & 6.00 & \multirow{2}{*}{4.47} & \multirow{2}{*}{$<0.001$} \\
\hline & after & 4.81 & 0.97 & 5.00 & 0.00 & 6.00 & & \\
\hline
\end{tabular}

*in the question concerning the number of months the scores ranged from 1.00 to 12.00

Legend: $\mathrm{n}$ - number of respondents; $\mathrm{M}$ - average; $M e$ - median; Min - minimum; Max - maximum; SD - standard deviation; $p$ - critical value; $Z$ - statistical value of Wilcoxon test for paired samples. Source materials: Study based on the authors' own research.

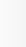

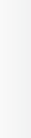


Specific allergen immunotherapy (SAI) was considered to be successful by $72.50 \%$ of the respondents. According to the study findings, it led to reducing the incidence of allergy symptoms (from $\mathrm{Me}=4.00$ to $2.00 ; \mathrm{p}<0.001$ ) and decreased their intensity (from $\mathrm{Me}=4.00$ to $2.00 ; \mathrm{p}<0.001$ ). An application of this type of desensitization allowed for reducing the number of additional anti-allergic medicines taken by the patients (from $\mathrm{Me}=4.00$ to $2.00 ; \mathrm{p}<0.001$ ). Moreover, the therapy improved patients' general well-being (from $\mathrm{Me}=4.00$ to $5.00 ; \mathrm{p}<0.001$ ) and life satisfaction (from $\mathrm{Me}=4.00$ to $5.00 ; \mathrm{p}<0.001$ ). These results are consistent with the findings of the study conducted by Gniadek et al. [8], which showed that the application of specific allergen immunotherapy was connected with the improvement of the quality of life.

Despite the growing number of patients diagnosed with allergic diseases [1-2] and the fact that, according to predictions, in 2025 as many as 50\% of Europeans will be suffering from at least one allergic disease [2], there is still a shortage of research concerning the efficiency of various anti-allergic therapies and their influence on patients' functioning, their quality of life and psychological well-being. Consequently, it is essential to take further steps aimed at the assessment of existing forms of treatment and adjusting them to patients' needs and expectations.

\section{CONCLUSIONS}

Majority of respondents considered specific allergen immunotherapy to be an effective form of treatment. Moreover, its application had a positive influence on patients' functioning and increased their well-being and life satisfaction. The findings of the study also justify the need for conducting a detailed continuous (before, during and after therapy) assessment of the quality of life and functioning of patients undergoing specific allergen immunotherapy.

\section{Wybrane aspekty funkcjonowania pacjentów przed i po odczulaniu swoistą immunoterapią alergenową}

\section{WPROWADZENIE}

Choroby alergiczne są coraz bardziej powszechnym problemem zdrowotnym w Polsce [1], co jest również zgodne $\mathrm{z}$ trendem europejskim [2]. The European Academy of Allergy and Clinical Immunology [2] prognozuje, że w 2025 roku choroby alergiczne będą dotyczyły co drugiej osoby zamieszkującej teren Europy. Należy podkreślić, że choroby alergiczne wpływają istotnie na codzienne funkcjonowanie powodując różnego typu dolegliwości np. utrzymujący się nieżyt nosa, kaszel, łzawienie oczu [3] oraz ograniczenia mające znaczenie dla jakości życia tych pacjentów [4-5]. Wśród dostępnych metod leczenia coraz bardziej popularna staje się swoista immunoterapia alergenowa, która wydaje się być korzystna szczególnie ze względu na komfort pacjenta oraz zniesienie większości objawów związanych z alergią [3].

\section{CEL PRACY}

Celem niniejszego badania była ocena jakości życia oraz codziennego funkcjonowania $\mathrm{w}$ grupie pacjentów, którzy stosowali terapię swoistą alergenową (SAI) od przynajmniej 10 miesięcy.

\section{MATERIAŁ I METODY}

Badania przeprowadzono od 31 lipca do 31 sierpnia 2018 roku w dwóch małopolskich placówkach zajmujących się leczeniem alergii z użyciem swoistej immunoterapii alergenowej.

Przed rozpoczęciem tego badania uzyskano zgodę od Zarządu obydwu wskazanych miejsc. Każdy pacjent uzyskał informacje dotyczące: dobrowolności udziału w badaniu, zapewnienia anonimowości oraz wykorzystania uzyskanych wyników wyłącznie do celów naukowych. Uczestnicy zostali poinformowani o celu prowadzonego badania oraz możliwości wycofania się w każdym momencie. Badanie to zostało przeprowadzone zgodnie $z$ Deklaracją Helsińską. Każdy uczestnik wyraził świadomą zgodę na udział w niniejszym projekcie. Przebadano 80 osób, które w momencie rozpoczęcia badań stosowały przynajmniej od 10 miesięcy immunoterapię swoistą alergenową. Przedział wiekowy uczestników wynosił 18 do 63 lat $(\mathrm{M}=33,90 ; \mathrm{SD}=7,29)$. Zastosowane narzędzia obejmowały ankietę własnego autorstwa oraz skróconą wersję skali World Health Organization Quality of Life-BREF (WHOQOL-BREF), które zostały przedstawione poniżej.

Autorski kwestionariusz składał się z dwóch części. Pierwsza z nich obejmowała pytania dotyczące danych socjodemograficznych tj.: płeć, wiek, miejsce zamieszkania, wykształcenie, typ wykonywanej pracy oraz oceny sytuacji ekonomicznej. Umieszczono w niej również pytania dotyczące alergii tj.: sposobu zdiagnozowania alergii, typu alergii, objawów towarzyszących, występowania astmy, typu stosowanych środków związanych $\mathrm{z}$ farmakoterapią i immunoterapią, okresu (liczonego $\mathrm{w}$ miesiącach) stosowania immunoterapii swoistej alergenowej oraz zalet i wad tego sposobu terapii. Z kolei, druga część zawierała pytania dotyczące porównania stanu przed i po zastosowaniu SAI. Zapytano o stan zdrowia, częstość, nasilenie i uciążliwość objawów alergii oraz o konsekwencje tego stanu tj.: poziom gotowości do podejmowania aktywności fizycznej w momencie nasilenia objawów, konieczność modyfikacji codziennych nawyków, częstość 
występowania obniżonego nastroju oraz złości wynikających $\mathrm{z}$ alergii, a także o satysfakcję życiową. Zmienne te oceniono stosując skalę od 0 do 6. Opis tej skali dostosowany był do treści poszczególnych pytań. Przykładowo dla oceny „ogólnego stanu zdrowia”, 0 oznaczało „bardzo zły” a 6 odpowiadało „bardzo dobry”.

The World Health Organization Quality of Life BREF (WHOQOL-BREF) - skala pozwalająca na badanie jakości życia, zawierająca 26 pytań dotyczących jakości życia związanej z różnymi aspektami: zdrowotnym, fizycznym, psychologicznym, socjalnym i środowiskowym [6]. Każde pytanie oceniane jest $\mathrm{z}$ użyciem skali Likerta od 1 do 5, a jej opis dostosowany jest do poszczególnych zagadnień. Indywidualne wyniki można uzyskać w odniesieniu do ogólnego stanu zdrowia, ogólnej jakości życia oraz każdego z jej wymiarów. Istnieją dwa sposoby obliczania wyników, w niniejszej pracy zastosowano skalę od 1 do 100, która umożliwia dokonywanie porównań $\mathrm{z}$ rezultatami innych badań podejmujących zagadnienie jakości życia [7].

Analiza statystyczna uzyskanych wyników została przeprowadzona $\mathrm{z}$ wykorzystaniem programu Statistica 13.1. Zgodność z rozkładem normalnym zweryfikowano testem Shapiro-Wilka. Ze względu na brak powyżej wymienionej zgodności, zastosowano test kolejności par Wilcoxona, który umożliwia zbadanie zmienności wewnątrzgrupowej związanej z powtarzanym pomiarem (przed i po zastosowaniu immunoterapii swoistej alergenowej). We wszystkich analizach przyjęto poziom istotności $\alpha=0.05$. Osoby badane były proszone o ocenę aktualnej jakości życia w oparciu o skalę WHOQOL-BREF. Ponadto, uczestnicy dokonali oceny (bieżącej i retrospektywnej) wybranych aspektów funkcjonowania $\mathrm{z}$ użyciem autorskiego kwestionariusza.

\section{WYNIKI}

Przedział stosowania immunoterapii swoistej alergenowej wynosił od 10 do 80 miesięcy $(M=26,81$; $S D=14,89)$. Warto podkreślić, że $72,50 \%$ badanych oceniło ten typ odczulania jako skuteczny, a pozostali uczestnicy mieli

Tab. 1. Ocena jakości życia oraz zdrowia z wykorzystaniem skróconej wersji skali World Health Organization Quality of Life-BREF (WHOQOL-BREF)

\begin{tabular}{|l|c|c|c|c|c|c|c|}
\hline $\begin{array}{c}\text { WHOQ0L-BREF } \\
\text { [\%] }\end{array}$ & $\mathbf{M}$ & Me & Min & Max & $\mathbf{Q 1}$ & Q3 & SD \\
\hline Jakość życia & 86,75 & 80,00 & 60,00 & 100,00 & 80,00 & 100,00 & 11,45 \\
\hline Zdrowie & 76,50 & 80,00 & 40,00 & 100,00 & 60,00 & 80,00 & 13,03 \\
\hline $\begin{array}{l}\text { Dziedzina } \\
\text { fizyczna }\end{array}$ & 72,49 & 69,00 & 38,00 & 100,00 & 69,00 & 81,00 & 12,38 \\
\hline $\begin{array}{l}\text { Dziedzina } \\
\text { psychologiczna }\end{array}$ & 77,25 & 75,00 & 44,00 & 100,00 & 69,00 & 88,00 & 11,15 \\
\hline $\begin{array}{l}\text { Dziedzina } \\
\text { socjalna }\end{array}$ & 74,61 & 75,00 & 19,00 & 100,00 & 69,00 & 81,00 & 18,16 \\
\hline $\begin{array}{l}\text { Dziedzina } \\
\text { środowiskowa }\end{array}$ & 72,58 & 75,00 & 44,00 & 100,00 & 63,00 & 81,00 & 11,99 \\
\hline
\end{tabular}

Wyjaśnienie skrótów: $\mathrm{n}$ - liczba osób badanych; M- średnia; Me - mediana; Min - minimum; Max - maksimum; SD - odchylenie standardowe; Q1 - kwartyl dolny; Q3 - kwartyl górny; WHOQOL-BREF - skrócona wersja kwestionariusza World Health Organization Quality of Life.

Źródło: Opracowanie na podstawie badań własnych.

Vol.18, $\mathrm{Nr} 4(69) / 2019$ trudność z dokonaniem jednoznacznej oceny efektywności tego podejścia.

Jakość życia mierzona z wykorzystaniem kwestionariusza WHOQOL-BREF została oceniona: u 31 osób $(38,75 \%)$ jako „bardzo dobra”, u 45 osób (56,25\%) jako „dobra”, a u 4 osób (5,00\%) jako „ani dobra, ani zła”. Średnie oceny jakości życia i zdrowia przedstawiały się następująco: jakość życia - 86,75\%, a zdrowie - 76,50\%. Szczegółowe wyniki zestawiono w Tabeli 1.

Większość badanych osób była zadowolona ze swojego stanu zdrowia, 9 osób $(11,25 \%)$ wskazało, że są „bardzo zadowolone”, 50 osób (62,50\%), że są „zadowolone”, 19 osób (23,75\%), że są „ani zadowolone, ani niezadowolone”, 2 osoby (2,50\%), że są „niezadowolone”.

W odniesieniu do oceny funkcjonowania przed i po zastosowaniu SAI zaobserwowano istotne statystycznie zmiany dotyczące m.in.: ogólnego dobrostanu $(\mathrm{Me}=4,0$ na 5,0; $<<0,001$, poziomu nasilenia objawów alergii $(\mathrm{Me}=4,0$ na 2,$0 ; \mathrm{p}<0,001)$, częstości występowania objawów alergii $(\mathrm{Me}=4,00$ na 2,00; $\mathrm{p}<0,001)$ oraz poziomu

Tab. 2. Ocena funkcjonowania osób stosujących immunoterapię swoistą alergenową (SAl) przed i po jej wdrożeniu

\begin{tabular}{|c|c|c|c|c|c|c|c|c|}
\hline $\begin{array}{l}\text { Skala ocen } \\
\text { [0-6 pkt.* }\end{array}$ & SAI & M & SD & Me & Min & Max & $\mathbf{Z}$ & p \\
\hline \multirow{2}{*}{ Ogólny dobrostan } & przed & 4,26 & 1,12 & 4,00 & 0,00 & 6,00 & \multirow{2}{*}{4,02} & \multirow{2}{*}{$<0,001$} \\
\hline & po & 4,85 & 0,86 & 5,00 & 2,00 & 6,00 & & \\
\hline \multirow{2}{*}{$\begin{array}{l}\text { Poziom nasilenia } \\
\text { objawów alergii }\end{array}$} & przed & 4,36 & 1,14 & 4,00 & 1,00 & 6,00 & \multirow{2}{*}{7,17} & \multirow{2}{*}{$<0,001$} \\
\hline & po & 2,38 & 1,30 & 2,00 & 0,00 & 6,00 & & \\
\hline \multirow{2}{*}{$\begin{array}{l}\text { Częstość występowania } \\
\text { objawów alergii }\end{array}$} & przed & 4,23 & 1,18 & 4,00 & 1,00 & 6,00 & \multirow{2}{*}{6,90} & \multirow{2}{*}{$<0,001$} \\
\hline & po & 2,28 & 1,25 & 2,00 & 0,00 & 6,00 & & \\
\hline \multirow{2}{*}{$\begin{array}{l}\text { Liczba miesięcy w roku, } \\
\text { w których objawy alergii } \\
\text { nasilały się }\end{array}$} & przed & 5,04 & 2,66 & 4,00 & 1,00 & 12,00 & \multirow{2}{*}{5,36} & \multirow{2}{*}{$<0,001$} \\
\hline & po & 3,55 & 2,29 & 3,00 & 1,00 & 12,00 & & \\
\hline \multirow{2}{*}{$\begin{array}{l}\text { Częstość korzystania } \\
\text { zleków przeciwalergicznych }\end{array}$} & przed & 4,06 & 1,67 & 4,00 & 0,00 & 6,00 & \multirow{2}{*}{6,17} & \multirow{2}{*}{$<0,001$} \\
\hline & po & 2,29 & 1,82 & 2,00 & 0,00 & 6,00 & & \\
\hline \multirow{2}{*}{$\begin{array}{l}\text { Poziom uciążliwości } \\
\text { objawów alergii } \\
\text { w codziennym } \\
\text { funkcjonowaniu }\end{array}$} & przed & 4,01 & 1,32 & 4,00 & 1,00 & 6,00 & \multirow{2}{*}{6,87} & \multirow{2}{*}{$<0,001$} \\
\hline & po & 1,95 & 1,40 & 2,00 & 0,00 & 6,00 & & \\
\hline \multirow{2}{*}{$\begin{array}{l}\text { Chęć podejmowania } \\
\text { aktywności sportowych } \\
\text { w czasie nasilenia } \\
\text { objawów alergii }\end{array}$} & przed & 2,28 & 1,68 & 2,00 & 0,00 & 6,00 & \multirow{2}{*}{5,05} & \multirow{2}{*}{$<0,001$} \\
\hline & po & 3,39 & 1,72 & 4,00 & 0,00 & 6,00 & & \\
\hline \multirow{2}{*}{$\begin{array}{l}\text { Konieczność } \\
\text { wprowadzenia zmian } \\
\text { nawyków w codziennym } \\
\text { funkcjonowaniu } \\
\text { z powodu objawów alergii }\end{array}$} & przed & 2,42 & 1,57 & 3,00 & 0,00 & 6,00 & \multirow{2}{*}{4,81} & \multirow{2}{*}{$<0,001$} \\
\hline & po & 1,63 & 1,50 & 1,00 & 0,00 & 6,00 & & \\
\hline \multirow{2}{*}{$\begin{array}{l}\text { Częstość występowania } \\
\text { obniżonego nastroju } \\
\text { i złości, spowodowanych } \\
\text { nasilonymi objawami } \\
\text { alergii }\end{array}$} & przed & 3,21 & 1,55 & 3,00 & 0,00 & 6,00 & \multirow{2}{*}{6,63} & \multirow{2}{*}{$<0,001$} \\
\hline & po & 1,88 & 1,36 & 2,00 & 0,00 & 6,00 & & \\
\hline \multirow{2}{*}{$\begin{array}{l}\text { Poziom ogólnej satysfakcji } \\
\text { życiowej }\end{array}$} & przed & 4,28 & 0,90 & 4,00 & 1,00 & 6,00 & \multirow{2}{*}{4,47} & \multirow{2}{*}{$<0,001$} \\
\hline & po & 4,81 & 0,97 & 5,00 & 0,00 & 6,00 & & \\
\hline
\end{tabular}

* $w$ pytaniu dotyczącym liczby miesięcy punktacja mieściła się $w$ przedziale od 1,00 do 12,00

Wyjaśnienie skrótów: $\mathrm{n}$ - liczba osób badanych; $\mathrm{M}$ - średnia; Me - mediana; Min - minimum; Max - maksimum; SD - odchylenie standardowe; p - wartość krytyczna testu;

Z - wartość statystyki testu kolejności par Wilcoxona.

Źródło: Opracowanie na podstawie badań własnych. (n)

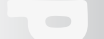

(1)


ogólnej satysfakcji życiowej ( $\mathrm{Me}=4,00$ na 5,00; $\mathrm{p}<0,001)$. Pełne informacje dotyczące wyników uzyskanych z wykorzystaniem autorskiego kwestionariusza przedstawiono w Tabeli 2.

\section{DYSKUSJA}

Celem niniejszego badania była ocena jakości życia oraz wpływu zastosowanego leczenia na funkcjonowanie w grupie pacjentów, którzy stosowali immunoterapię swoistą alergenową od przynajmniej 10 miesięcy. Przebadano 80 osób dorosłych, które leczyły się w dwóch małopolskich placówkach umożliwiających tego typu odczulanie. Uczestnicy średnio od 26 miesięcy stosowali już immunoterapię swoistą alergenową. W szystkie osoby badane wypełniły autorski kwestionariusz oraz wersję skali WHOQOL-BREF.

SAI została oceniona jako skuteczna przez 72,50\% osób badanych. Zgodnie z uzyskanymi wynikami umożliwiła ona zredukowanie częstości występowania objawów alergii $(\mathrm{Me}=4,00$ do 2,00; $\mathrm{p}<0,001)$ oraz zmniejszenie ich nasilenia $(\mathrm{Me}=4,00$ do 2,$00 ; \mathrm{p}<0,001)$. Zastosowanie tego typu odczulania pozwoliło na zmniejszenie liczby dodatkowo przyjmowanych leków o charakterze przeciwalergicznym ( $\mathrm{Me}=4,00$ do 2,00; $\mathrm{p}<0,001)$. Ponadto, wpłynęło to na poprawę w zakresie: ogólnego dobrostanu $(\mathrm{Me}=4,00$ do 5,$00 ; \mathrm{p}<0,001)$ oraz satysfakcji życiowej $(\mathrm{Me}=4,00$ do 5,$00 ; \mathrm{p}<0,001)$. Jest to zgodne $\mathrm{z}$ wynikami badań przeprowadzonych przez Gniadek et al. [8], w których stosowanie immunoterapii swoistej było związane z poprawą jakości życia.

Pomimo, iż liczba osób, u których diagnozuje się choroby alergiczne wciąż rośnie [1-2], a do 2025 zgodnie z prognozami 50\% Europejczyków będzie zmagać się z przynajmniej jedną taką chorobą [2], wciąż widoczna jest luka w badaniach dotyczących skuteczności różnego typu terapii przeciwalergicznych, a także ich wpływu na funkcjonowanie pacjentów, ich jakość życia i dobrostan psychiczny. W konsekwencji istotne jest podjęcie dalszych działań mających na celu dalszą ewaluację istniejących metod leczenia oraz dopasowanie ich do potrzeb pacjentów.

\section{WNIOSKI}

Większość osób badanych immunoterapię swoistą alergenową jako skuteczny typ terapii. Ponadto, jej zastosowanie wpłynęło na poprawę funkcjonowania pacjentów, wzmocnienie ich dobrostanu oraz satysfakcji życiowej. Uzyskane wyniki wskazują również na zasadność prowadzenia szczegółowej oceny jakości życia i funkcjonowania pacjentów stosujących SAI w sposób ciągły (przed, w trakcie i po SAI).

\section{REFERENCES/PIŚMIENNICTWO}

1. Samoliński B, Raciborski F, Lipiec A i wsp. Epidemiologia chorób alergicznych w Polsce (ECAP). Alergologia Polska-Polish Journal of Allergology. 2014;1(1): 10-18. doi: https://doi.org/10.1016/j.alergo.2014.03.008.

2. The European Academy of Allergy and Clinical Immunology 2015. Pobrane z: https:// www.eaaci.org/documents/EAACl_Advocacy_Manifesto.pdf (dostęp: 1.09.2019)

3. Gawlik R, Zagórny G, Bożek A. Farmakoekonomiczne aspekty zastosowania immunoterapii alergenowej w leczeniu alergicznego nieżytu nosa i astmy. Alergologia Polska-Polish Journal of Allergology. 2017;4 (2): 63-67.

4. Stanisławska M, Iwanowska K, Jurczak A i wsp. Jakośćżycia pacjentów z alergicznym nieżytem nosa. Family Medicine \& Primary Care Review. 2015;17 (3): 205-209.

5. Ścibor M, Balcerzak B, Czarnecka Ż, Malinowska-Cieślik M. Ocena jakości życia pacjentów z astmą oskrzelową mieszkających w Krakowie w strefach różniących się stężeniem pyłu zawieszonego w powietrzu (PM10). Medycyna ŚrodowiskowaEnvironmental Medicine. 2015;1 (18): 45-53.

6. The World Health Organization. The World Health Organization Quality of Life (WHOQOL) - BREF 2004. Pobrane z: https://www.who.int/substance_abuse/ research_tools/en/polish_whoqol.pdf (dostęp: 1.09.2019)

7. Golicki D, Styczen P, Szczepkowski M. Quality of life in stoma patients in Poland: multicentre cross-sectional study using WH0Q0L-BREF questionnaire. Przegląd Epidemiologiczny. 2013;67 (3): 491-496.

8. Gniadek A, Malinowska-Lipień I, Solarz P, Marcisz E. Jakość życia chorych z astmą oskrzelową leczonych immunoterapią swoistą. Pielęgniarstwo XXI wieku. 2015;51 (2): 5-10. doi: 10.12923/p21w-2015-2/11.

Manuscript received/Praca zgłoszona do czasopisma: 20.09.2019

Manuscript accepted/Praca zaakceptowana do druku: 28.10.2019

Translation/Tłumaczenie: Elżbieta Potępa 